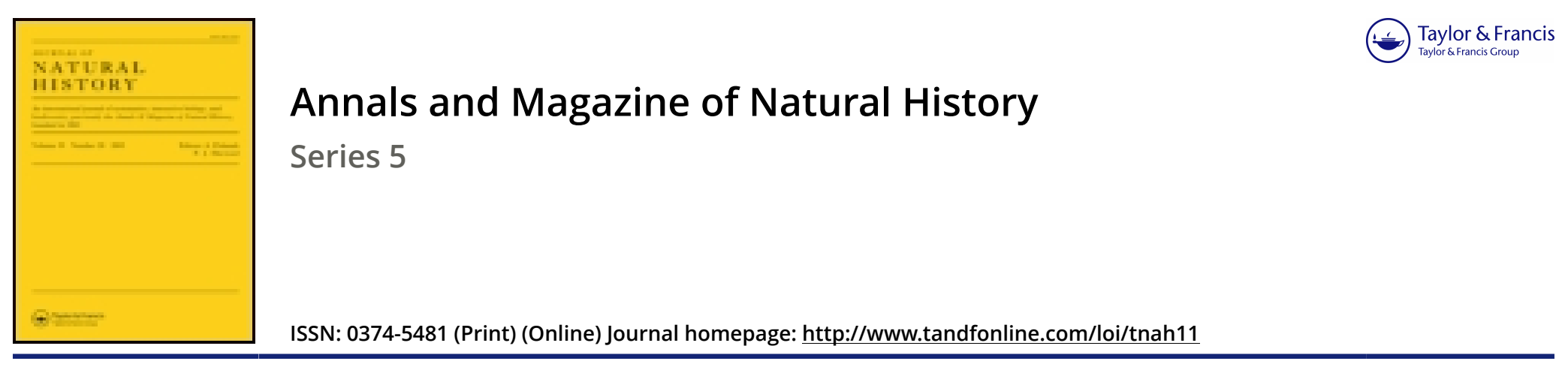

\title{
On some remarkable fossil fishes from the Devonian rocks of Scaumenac Bay, in the Province of Quebec
}

\section{J.F. Whiteaves}

To cite this article: J.F. Whiteaves (1881) On some remarkable fossil fishes from the Devonian rocks of Scaumenac Bay, in the Province of Quebec , Annals and Magazine of Natural History, 8:44, 159-162, DOI: $10.1080 / 00222938109487434$

To link to this article: http://dx.doi.org/10.1080/00222938109487434

$$
\text { 曲 Published online: } 09 \text { Oct } 2009 .
$$

\section{Submit your article to this journal ¿}

Џ Article views: 4

Q View related articles $\sqsubset$

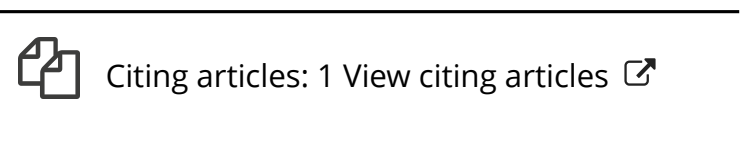


suggestive explanations as to the causes of these illusions. Dr. Beddoe treats of the Ethnology of the Hindoo-Koosh; H. Charbonnier of specimens of the Pomarine Slua killed in Eingland; A. E. Hudd of the Local Lepidoptera (part 3); W. J. Sollas of the Structure and Life-history of a Sponge (Sycandra raphanus); A. Lejpner of Prolification in Cyclamen persicum; and C. Bucknell of the Local Fungi (part 3). Thus, touching the highest and the lowest in Biology, the Society fulfils its part in Natural History, supplementing the above with E. Wethered's valuable paper on Underground Temperature and G. F. Burder's Table of the Rainfall at Clifton in 1879.

\section{Proceedings of the Yorkshire Geological and Polytechnic Society. New series, vol. vii. part 3, for 1880. 8ro. Leeds, 1881 .}

Excepting the Marquis of Ripon's Presidential Address on the objects, work, and progress of the Society, and a paper by W. P. Sladen on the Structure of the Asteroidea, with special referenco to their ancestral relationship, this part iii. for 1880 is mainly composed of geological notos and memoirs, mostly with local bearings. The Raygill Fissure, the Creswell Caves, the Glacial Deposits near Bridlington and elsewhere, the Geology of Cleveland, the Fault in the Flamborough Chalk, Bones of Ctenodus, and the Fossil Fishes of the Coal-fields in Yorkshire are here treated of more or less fully.

\section{MISCELLANEOUS.}

On some remarkable fossil Fishes from the Devonian Rocks of Scaumenac Bay, in the Province of Quebec. By J. F. Whrteaves.

Imampdiately after my paper on the Canadian Pterichthys was written, Mr. A. H. Foord, of the Geological Survey of Canada, went down to the Baie des Chaleurs, and spent two months and a half of the summer of 1880 in a careful and systematic examination of the fish-bearing beds of the Devonian rocks of the north bank of the mouth of the Restigouche river. The exact locality at which the Pterichthys canadensis was found is not the Baie des Chaleurs proper, but Scaumenac (sometimes written Escuminac) Bay, Restigouche Harbour, in the county of Bonaventure. On the shores of this bay a series of shales, sandstones, and conglomerates, now known to be of Devonian age, are overlain, apparstly unconformably, by the red sandstones and conglomerates of the "Bonaventure Formation."

From these Devonian rocks Mr. Foord succeeded in obtaining a

* "On a new Species of Pterichthys, allied to Bothriolepis orvata, Eichwald," \&c., Amer. Journ. Sci. xx. p. 132, August 1880. 
large and interesting collection of fossil fishes. Fully four fifths of the entire number of specimens in this collection are referable to the genus Pterichthys, which at this locality seems to be represented by only one species, $P$. canadensis. Some of these are nearly perfect, and want only the fins proper and the tail, while others are mere isolated plates or detached portions of the pectoral spines. One of the specimens shows that the Canadian Pterichthys had two labial appendages or barbels attached to the front margin of the head. These barbels are almost exactly similar in shape to those indicated by dotted lines in the ideal representation of the genus Pterichthys on plate vi. of the 'Monographie des Poissons fossiles du Vieux Grès Rouge,' which Agassiz claims to have seen in his $P$. latus; but in $P$. canadensis the barbels are very close together at their bases. In two other specimens of a Pterichthys collected by Mr. Foord two remarkable, flattened, conical dermal processes are plainly visible on the helmet, one on each side of the orbital cavity. Posteriorly each process appears to fit into the angle formed by the junction of the prelateral with the nuchal and postlateral plates, while anteriorly they are each directed obliquely outward and forward across the prelaterals, which they partly cover. In one of the specimens the dermal processes, which are ornamented with a sculpture precisely similar to that of all the other plates, are half an inch long and $2 \frac{1}{2}$ lines broad near their base. They taper gradually from their base to an obtuse point, and are pressed close to the surface of the helmet.

In addition to these remains of Pterichthys, there are examples of eight or nine species of fossil fishes in Mr. Foord's collection, which belong to at least seven genera. The following is a brief description of the most striking characters of six of these species, the affinities of the remainder not having yet been satisfactorily ascertained:-

\section{Diplecanthus.}

Two specimens, one showing scales and longitudinally-grooved fin-spines, and the other a large portion of the body of a small smooth-scaled Diplacanthus, very like the D. striatus of Agassiz, and possibly identical with that species.

\section{Phaneropleuron curtum, sp. nov.}

Four crushed and distorted but nearly perfect examples and several fragments of a new species of 'Phaneropleurom, which differs from the P. Andersoni of Huxley, from the Old Red Sandstone of Dura Den, in its smaller size and in its much greater height or depth as compared with its length. P. Andersoni is represented as being about five and a half times as long as high, whereas in the largest specimen of $P$. curtum yet collected, which is 6 inches long, the length is not much more than twice the height. 
Eusthenopteron Foordi, nov. gen. et sp.

The name Eusthenopteron* is proposed for a supposed new genus, which resembles the Tristichopterus of Sir Philip Egerton in the shape and ornamentation of its scales and cranial plates, in the circumstance that the fin-rays of its anal and second dorsal fins are both supported by three osselets articulated to a broad interspinous apophysis, and in some other important particulars. But the vertebral centres of Tristichopterus are said to be ossified, and the osselets which support the rays of the lower lobe of the tail are described as "springing from eight or nine interspinous bones," whereas in Eusthenopteron the vertebral centres are not ossified, and the caudal osselets are articulated to the modified hæmal spines. In Eusthenopteron, too, the osselets and interspinous bones of the anal and second dorsal are larger than those of Tristichopterus, and different also in their shape and relative proportions.

The species, which is namod after its discoverer, Mr. A. H. Foord, may be recognized by its large size (it appears to have attained to a length of 2 feet or more) and by its narrowly elongated and acutely pointed first dorsal fin.

\section{Glyptolepis microlepidotus, Agassiz.}

A single nearly perfect specimen of a small-scaled Glyptotepis which cannot at present be distinguished from the above-named European species.

\section{Glyptolepis -}

A second species of Glyptolepis, apparently allied to the G. leptopterus of Agassiz, is indicated by a number of large detached scales, nearly an inch in diameter, which are associated with slender rib-bones, an operculum, and a fragment of a jaw with teeth on the same small slabs of shale.

\section{Cheirolepis canadensis, nov. sp.}

Four exquisitely preserved specimens, two of which are nearly perfect, of a large Cheirolepis, which rosembles the C. macrocephalus of $\mathrm{M}^{\circ} \mathrm{Coy}$ and the C. Cumingice of Agassiz in the size, contour, and sculpture of the scales of the body and fins, but which seems to differ from both in the relative position of its fins. In $C$. canadensis the ventrals are separated from the pectorals by a short interval and from the anal by a much longer one. In C. macrocephalus, on the other hand; the ventrals are represented by $\mathbf{I}^{\prime} \mathrm{Coy}$ as being nearer to the anal than they are to the pectorals, while in C. Cumingice, according to Hugh Miller, " the large pectorals almost encroach on the ventrals and the vontrals on the anal fin."

A more detailed description of these species will be found in the current number of the 'Canadian Naturalist' $t$.

\footnotetext{
* From $\epsilon \dot{v} \sigma \theta \epsilon \nu \eta \dot{s}$, stout, and $\pi \tau \epsilon ́ \rho o \nu$, a fin.

+ Vol. $x .$, new series.
} 
The existence of fossil plants as well as of fish-remains in the Devonian shales and sandstones of Seaumenac Bay was noticed by Dr. Abraham Gesner in 1842 ; and from these rocks Mr. Foord also obtained four species of ferns, which have recently been reported on by Principal Dawson.

The analogies between the fossil fauna of the fish-bearing beds of Scaumenac Bay and that of the Old Red Sandstone of Scotland and Russia are very striking. Pterichthys canadensis is still doubtfully distinct from the Bothriolepis ornata of Europe; the fragments of a Diplacanthus obtained by Mr. Foord have apparently much the same characters as the $D$. striatus of Agassiz; and the genus Phaneropleuron can now be shown to occur in the Devonian rocks of Canada as well as in those of Scotland. Eusthenopteron has many features in common with Tristichopterus; one species of Glyptolepis from Scaumenac Bay seems to be identical with the $G$. microlepidotus of Agassiz, from Lethen Bar, while the other bears a general resemblance to the $G$. leptopterus of the same author; and, lastly, Cheirolepis canadensis is certainly very olosely allied to two Scotch species.

These Devonian rocks at Scaumenac may have been of freshwater or estuarine origin; for no traces of any marine invertebrata have yet been detected in any of them, and the fossil fishes which they contain are invariably found associated with land plants.-Amer. Journ. Sci., June 1881.

\section{Migrations of the Poplar-Aphis (Pemphigus bursarius, Linn.). By M. J. Iichtenstein.}

In August of last year* I had the honour to announce to the Academy that the Aphis of the woody galls of the poplar (Pemphigus bursarius, partim, Linn., sub Aphis), placed under a bell glass on its escape from the galls, upon a plant of Filago germanica, produced young which, having in their turn acquired wings, had furnished sexual insects, laying in abundance upon fragments of poplar-bark placed within their reach in my study.

These sexual forms, which had no rostrum, copulated and furnished numerous fecundated ova. I say numerous, because the females themselves were very numerous; for each of them, like all the Pemphiginæ of which I know the sexual forms, has only a single orum in its body.

The copulation is preceded by several moults, which appear to me to be four in number. Although they had no mouth, and consequentiy could not feed, these little animals increased in size, like seeds put to soak. The male dies first, after having fecundated sereral females. When the female arrives at the moment of oviposition, we see issuing from her body very numerous white flaments,

* See 'Annals,' November 1880, p. 404. 